\title{
Seed performance of different corn genotypes during storage ${ }^{1}$
}

\author{
Tathiana Silva Timóteo ${ }^{2 *}$, Julio Marcos-Filho²
}

\begin{abstract}
Corn seed producers have shown significant concern about variations in the seed storage potential of different hybrids, which may not perform as desired. The objective of this research was to evaluate the effect of storage conditions on the physiological potential of seeds of different corn genotypes. Three experimental corn hybrids, each represented by three seed lots produced by Syngenta Seeds, were evaluated. Seeds were stored for fifteen months under three environments: cold and dry chamber $\left(10^{\circ} \mathrm{C}\right.$ and $30 \%$ relative humidity), laboratory environment, and controlled sub-optimal environment $\left(20^{\circ} \mathrm{C}\right.$ and $70 \%$ relative humidity). Seed performance was evaluated every three months by germination, accelerated aging and cold tests. Activity of the catalase, alcohol dehydrogenase and $\alpha$-amilase enzymatic systems was also determined using electrophoresis. The storability of corn seeds from different genotypes can be consistently evaluated by associating germination and vigor test results with isoenzymatic activity. Storage under controlled sub-optimal temperature and relative humidity is an efficient procedure to provoke differences in intensity and speed of deterioration in corn seeds of different genotypes.
\end{abstract}

Index terms: storability, deterioration, enzymes, vigor.

\section{Desempenho de sementes de diferentes genótipos de milho durante o armazenamento}

RESUMO - Empresas produtoras de sementes de milho têm demonstrado preocupação com variações no potencial de armazenamento de sementes de diferentes híbridos, que podem não apresentar o desempenho desejado. Objetivou-se com esse trabalho os efeitos de ambientes de armazenamento sobre o potencial fisiológico de sementes de diferentes genótipos de milho. Foram avaliadas sementes de três híbridos experimentais de milho, representados por três lotes produzidos pela empresa Syngenta Seeds, armazenados durante quinze meses, em três ambientes: câmara fria e seca $\left(10{ }^{\circ} \mathrm{C} / 30 \%\right.$ de umidade relativa do ar), laboratório e ambiente sub-ótimo controlado $\left(20^{\circ} \mathrm{C} / 70 \%\right.$ de umidade relativa do ar). O desempenho das sementes foi avaliado em épocas trimestrais, por meio de testes de germinação, envelhecimento acelerado e frio; foi, também, determinada a atividade dos sistemas isoenzimáticos catalase, álcool desidrogenase e $\alpha$-amilase, por meio da técnica de eletroforese. Verificou-se que o potencial de armazenamento de sementes de diferentes genótipos de milho é avaliado associando-se resultados de testes de germinação e vigor com avaliações da atividade de isoenzimas. O armazenamento em ambiente controlado sob condições sub-ótimas de temperatura e umidade relativa do ar, é adequado para promover diferenças na intensidade e velocidade de deterioração de sementes de genótipos de milho.

Termos para indexação: potencial de armazenamento, deterioração, enzimas, vigor.

\section{Introduction}

Different cultivars of the same species may differ as to the vigor and longevity. Proper storage allows for the conservation of seed viability for prolonged periods. According to Stein et al. (1974), many factors affect the performance of seeds during storage, including genotype, the type of seed, maturation stage, treatments prior to storage, viability and initial water content of the seeds, temperature and relative humidity, oxygen pressure during storage and degree of infection by fungi and bacteria.
Andrade and Borba (1993) noted that several cultivars of the same species may differ as to the vigor and storage potential.

Several authors have emphasized that the main factors responsible for the conservation of seeds during storage are the temperature and the moisture content of the seeds. Harrington (1972), stated that the maintenance of low temperature reduces the activity of enzymes involved in the breathing process and, consequently, the speed of decline in viability of the orthodox seeds during storage. The deterioration can not be avoided but can be minimized during

${ }^{1}$ Submitted on 07/30/2012. Accepted for publication on 11/26/2012.

${ }^{2}$ Departamento de Produção Vegetal, USP/ESALQ, 13418-900 - Piracicaba, SP, Brasil.

*Corresponding author<tasiti@yahoo.com.br>

Journal of Seed Science, v.35, n.2, p.207-215, 2013 
storage under appropriate conditions (Santos et al., 2004).

High temperature and relative humidity during storage of seeds contribute to their deterioration by promoting degenerative changes such as destabilization in the activities of enzymes and the destructuring and eventual loss of integrity of the cell membranes system, caused mainly by lipid peroxidation due to increased reactive oxygen species (ROS) (Alscher et al., 2002).

The study of the aging process of seeds by determining changes in enzyme groups has allowed for the identification of starting points of damages that occur, as well as the attainment of more reliable information about the causes of deteriorative events and their consequences.

According to Copeland and McDonald (2001), the most sensitive evaluations to detect the start of deterioration of the seeds are related to the activity of enzymes associated with the biosynthesis of new tissue, since with the process of deterioration, the enzymes become less efficient in exerting their catalytic activity.

Although there are studies related to changes in the physiological potential of corn seeds during storage, much remains to be clarified in this process, since the literature contains very limited information on the subject. Considering that the main challenge of the researches on seed storage is to identify parameters sensitive enough to detect the start and progress of decay, monitoring these changes may constitute an efficient tool for the assessment of the storage potential of seeds of different genotypes.

The present study aimed to assess the effects of storage environments on the physiological potential of seeds of different corn genotypes, trying to identify possible causes of physiological changes and differences in their performance.

\section{Material and Methods}

The research was carried out in the Laboratory of Seed Analysis, Department of Plant Production, "Luiz de Queiroz" College of Agriculture, University of São Paulo (USP/ ESALQ), Piracicaba - SP, and in the Central Seed Laboratory of the Department of Agriculture, Federal University of Lavras (UFLA), Lavras - MG.

Three experimental hybrids of corn (2008/2008) produced by Syngenta Seeds were used, identified as A, B and C, each represented by three lots of seeds treated with fungicide and insecticide and stored in three environments. According to information from the producer, these hybrids have different behaviors regarding storage.

The initial physiological potential of the lots of each hybrid was distinguished by artificial aging during different periods: a) hybrid $A$, lot 1 , unaged; lot 2 , aged at $41{ }^{\circ} \mathrm{C} / 72 \mathrm{~h}$ and lot $3,41^{\circ} \mathrm{C} / 96 \mathrm{~h}$; b) hybrid $B$, lot 4 , unaged; lot 5, aged at $41{ }^{\circ} \mathrm{C} / 96 \mathrm{~h}$ and lot $6,41^{\circ} \mathrm{C} / 120 \mathrm{~h}$; c) hybrid $C$, lot 7 , unaged; lot 8 , aged at $41{ }^{\circ} \mathrm{C} / 72 \mathrm{~h}$ and lot $9,41^{\circ} \mathrm{C} / 96 \mathrm{~h}$. After artificial aging, a careful manual homogenization was performed and, after that, the seeds were placed to dry at room temperature until they reached water levels close to the initial levels (about 9\%).

The seeds of each lot were packed in muslin bags and stored in three environments: cold and dry chamber $\left(\mathrm{A}_{1}\right)$, at $10{ }^{\circ} \mathrm{C}$ and $30 \%$ relative humidity, laboratory environment $\left(\mathrm{A}_{2}\right)$ with daily record of temperature and relative humidity, and controlled environment $\left(\mathrm{A}_{3}\right)$, seeking sub-optimal conditions at $20{ }^{\circ} \mathrm{C}$ and $70 \%$ relative humidity. The latter was established by use of $\mathrm{NaCl}$ solution in a plastic container $(35 \times 20 \times 11 \mathrm{~cm})$ positioned inside a plastic box $(51 \times 36 \times 15 \mathrm{~cm})$, where seeds were also maintained stored in muslin bags. To definition of the volume of $\mathrm{NaCl}$ solution was based on the ratio of the solution used in the accelerated aging test using a saturated $\mathrm{NaCl}$ solution (40 g salt per $100 \mathrm{~mL}$ water), according to Jianhua and McDonald (1997); solutions with different concentrations of salt were used, depending on the amount of seeds from each lot and hybrid, aiming to keep the inside of the box with relative humidity around $70 \%$. The relative humidity inside the plastic boxes was monitored periodically by a thermo-hygrometer placed inside. Throughout the storage period, the boxes containing the seeds were kept in a dry chamber at $20{ }^{\circ} \mathrm{C}$ and $50-60 \%$ relative humidity so that possible variations in external temperature could not influence the relative humidity inside the boxes. The storage period was 15 months, and the seeds were subjected to different assessments, with quarterly intervals.

Before the start of each of these assessments, the standardization of the moisture content of the seeds was performed by placing the samples in a laboratory environment for approximately 7 days. This procedure was necessary because the seeds remained exposed to different storage conditions, presenting variations in moisture contents. The temperature and relative humidity in the three environments throughout the storage period were monitored through thermo-hygrometer records.

Seed performance was evaluated by the tests: moisture content: oven method at $105{ }^{\circ} \mathrm{C}\left( \pm 3{ }^{\circ} \mathrm{C}\right)$ for 24 hours (Brasil, 2009), in two samples per lot; germination: conducted with four replications of 50 seeds, at $25{ }^{\circ} \mathrm{C}$, according to Brasil (2009); accelerated aging: the method of mini-chambers was used, in which the seeds were distributed in a single layer on a screen suspended inside a plastic box containing $40 \mathrm{~mL}$ of water. The seeds remained incubated for 96 hours at $41{ }^{\circ} \mathrm{C}$ (Marcos-Filho, 1999). After this period, a germination test was conducted and the percentage of normal 
seedlings at the fourth day after sowing was considered; cold test: conducted with four replications of 50 seeds. Plastic trays of $34 \times 23 \times 7 \mathrm{~cm}$ were used, with $1 \mathrm{~kg}$ of a mixture of soil and sand in the ratio of 1:3. In each tray were distributed two replications of 50 seeds, then they were covered with $1 \mathrm{~kg}$ of the same substrate, according to Caseiro and Marcos-Filho (2000). Water availability of the substrate was adjusted to $70 \%$ of its retention capacity. The water used was previously cooled to $10{ }^{\circ} \mathrm{C}$. To reduce evaporation, each tray was placed inside a transparent plastic bag and then kept in a cold chamber at $10^{\circ} \mathrm{C}$ for seven days. After this period, the trays were transferred to a germinator at $25^{\circ} \mathrm{C}$, and the record of the percentage of seedlings was held on the fifth day.

For the evaluations of enzymatic activity, two seed samples were collected from the three hybrids, stored in the three environments, at the beginning and at 3, 6, 9, 12 and 15 months of storage and conserved in a freezer at $-80{ }^{\circ} \mathrm{C}$, until the completion of the electrophoretic analysis. The enzymatic activity of the lots of seeds subjected to zero (lots 1, 4 and 7) and 96 hours (lots 3, 5 and 9) of artificial aging was evaluated and compared. Subsequently, samples were ground in a mill using liquid nitrogen and manually macerated, in the presence of the antioxidant polyvinylpyrrolidone (PVP) and stored in a freezer at $-80^{\circ} \mathrm{C}$.

Subsamples of $100 \mathrm{mg}$ of macerated material were collected, to which an extraction buffer (Tris $\mathrm{HCl} 0.2 \mathrm{M} \mathrm{pH}$ 8.0) was added in the ratio of 2.5 times the mass of each sample and $0.1 \% \beta$ - mercaptoethanol, and then the samples were vortexed for 30 seconds. The material was placed in the refrigerator overnight and was then centrifuged at 14,000 rpm for 30 minutes at $4{ }^{\circ} \mathrm{C}$. $40 \mu \mathrm{L}$ of the supernatant were applied to the running gel (separating gel, $7.5 \%$ polyacrylamide; and concentrating gel, $4.5 \%$ polyacrylamide) and starch gel for the $\alpha$-amylase enzyme system (separating gel, $7.5 \%$ polyacrylamide and $0.5 \%$ soluble starch and concentrating gel, $4.5 \%$ polyacrylamide). The gel/electrode buffer system used was Tris-glycine $\mathrm{pH}$ 8.9. The runs were conducted at $120 \mathrm{~V}$ for 8 hours. After electrophoresis, the revelation of the gels to the alcohol dehydrogenase (ADH), catalase (CAT) and $\alpha$-amylase ( $\alpha$-AM) enzymes was made, according to the protocol proposed by Alfenas (2006). The evaluation of the electrophoretic profiles was performed based on the presence or absence and intensity of bands.

The experimental design used was completely randomized in a factorial design, evaluating the effects of environments and lots of seeds of each hybrid. Analyses were performed separately for each hybrid. Means were compared by Tukey test $(\mathrm{p} \leq 0.05)$. For the execution of statistical analysis the SISVAR program was used (Ferreira, 2008).

\section{Results and Discussion}

The conditions of temperature and relative humidity were different in the three environments, allowing the occurrence of variations in the deterioration rate of seeds of the three hybrids. In a cold and dry chamber $\left(\mathrm{A}_{1}\right)$, temperature and relative humidity were $10{ }^{\circ} \mathrm{C}$ and $30 \%$ throughout the storage period, with maximum variations of 2 percentage points in relative humidity.

In the controlled environment $\left(\mathrm{A}_{3}\right)$, the temperature was $20{ }^{\circ} \mathrm{C}$ during the entire storage period, and the relative humidity, around $50 \%$ with variations of 2 percentage points; but inside the plastic cases where seeds were placed, the relative humidity remained at around $70 \%$.

For the lab environment $\left(\mathrm{A}_{2}\right)$, temperature ranged from 14.0 to $31.0^{\circ} \mathrm{C}$ and relative humidity ranged from $72 \%$ to $83 \%$. Among the factors affecting seed conservation, relative humidity and temperature are of great importance in the evolution of deterioration. The variations in relative humidity observed during the 15 months of storage, when interacting with changes in temperature, could directly influence the maintenance of the physiological potential of seeds stored in the laboratory $\left(\mathrm{A}_{2}\right)$. Likewise, during the process of hydration and drying of the seeds that occurs in uncontrolled environments, as in a laboratory setting $\left(\mathrm{A}_{2}\right)$, usually a reduction of seed physiological potential occurs (Copeland and McDonald, 2001).

The seed lots of the three hybrids had moisture contents between $8.0 \%$ to $9.4 \%$ before storage. During storage, these values were between $6.2 \%$ to $8.7 \%$ when stored in a cold room $\left(\mathrm{A}_{1}\right), 10.1 \%$ to $12.0 \%$ in the laboratory environment $\left(\mathrm{A}_{2}\right)$ and $11.5 \%$ to $13.5 \%$ in a controlled environment $\left(\mathrm{A}_{3}\right)$. Due to the difference in moisture contents of seeds stored in the three environments, we performed an uniformization of the moisture content of the seeds stored in the laboratory environment $\left(\mathrm{A}_{2}\right)$ before the beginning of each evaluation period. This is important because there may be influence of results of the tests conducted. It is known that more humid seeds, within limits, may present faster germination, the same occurring with the initial development of seedlings. Likewise, in accelerated aging, the unevenness of water content in seeds generates a marked variation in the intensity of seed deterioration (Marcos-Filho et al., 1987).

After an uniformization of the moisture content in the laboratory environment $\left(\mathrm{A}_{2}\right)$, the lots of seeds of the three hybrids showed differences from 1.0 to 1.7 percentage points in water content. These values are relatively uniform and adequate before testing; by observing the data it can be noted that this parameter does not affect the behavior of the seeds during tests conducted during storage, since the variations 
were within tolerable limits, that is, 2 to 3 percentage points (Marcos-Filho, 1999).

The interaction between storage environments and lots of corn seeds was significant for all tests and at all times during storage. Evaluating the data from the germination, cold and accelerated aging tests, it was found that storage in a cold and dry chamber $\left(\mathrm{A}_{1}\right)$ provided the best conditions for the performance of lots of seeds of the three hybrids, as shown in Tables 1, 2 and 3. This was possible because the cold and dry chamber used in this research has a combination of temperature and relative humidity $\left(10{ }^{\circ} \mathrm{C}\right.$ and $\left.30 \% \mathrm{RH}\right)$ extremely favorable for corn seed storage. Under these conditions, seed conservation is favored, because the low temperature reduces the activity of enzymes involved in the breathing process of the seeds, and this process is a major contributor to the loss of seed viability during storage (Harrington, 1972). Furthermore, the low moisture content is an important factor for the conservation of seeds, which also contributed for the seed viability to be maintained during storage, since it is known that the moisture content is the most important factor among those affecting the storage potential and which most influences the respiratory rate of the seeds (Carvalho and Nakagawa, 2000).

For other environments $\left(A_{2}\right.$ and $\left.A_{3}\right)$, there were no differences in the behavior of seed lots during storage, a greater reduction in seed germination being observed in environment $\mathrm{A}_{3}$ (controlled environment), where high relative humidity conditions contributed for the lower germination presented by the seeds (Tables 1, 2 and 3).

The seeds in the lots not subjected to prior aging and, therefore, considered higher physiological potential lots (lots 1 , 4 and 7), when stored in the laboratory environment $\left(\mathrm{A}_{2}\right)$ and in the controlled environment at $20{ }^{\circ} \mathrm{C}$ and $70 \% \mathrm{RH}\left(\mathrm{A}_{3}\right)$, differed during storage. The seeds of lot 1 (hybrid $\mathrm{A}$ ) showed a decrease in germination only after 15 months of storage, reaching a value of $88 \%$ in the laboratory environment $\left(\mathrm{A}_{2}\right)$, while in the controlled environment $\left(\mathrm{A}_{3}\right)$ there was a decrease in 10 percentage points in the twelfth month of storage, determining germination of $89 \%$ (Table 1). For seeds of lot 7 (hybrid C), a similar behavior was observed, with a decrease in seed germination after 12 months of storage in the laboratory environment $\left(\mathrm{A}_{2}\right)$, and at nine months in the $A_{3}$ environment (Table 1). The decrease in germination of seeds stored in these environments may be related to environmental conditions. The seeds, being in an advanced storage period, have their physiological potential reduced due to the more advanced stage of the deterioration process.

The seeds of lot 4 (hybrid B) had germination higher than $95 \%$ throughout the storage period in environment $A_{2}$ (Table 1) and, despite a decrease having been verified in seed germination at 12 months of storage in environment $A_{3}$, the observed value $(87 \%)$ is still within the minimum standards for marketing, thus underscoring the superiority of this hybrid in relation to others.

Also according to Table 1, a decrease was observed in the germination, in the first three months of storage in lots that were subjected to prior aging, that is, considered as intermediate (lots 2,5 and 8) and reduced (lots 3,6 and 9) physiological potential in the laboratory environment $\left(\mathrm{A}_{2}\right)$. For the controlled environment at $20{ }^{\circ} \mathrm{C}$ and $70 \% \mathrm{RH}\left(\mathrm{A}_{3}\right)$, the decrease in seed germination of the same lots was observed also in the first three months of storage, but with more significant decrease (Table 1). Decreases that occurred more quickly in the germination of seeds in lots with low or intermediate physiological potential were not surprising, because samples were subjected to prior aging for a relatively long period, causing the most advanced degree of deterioration and, thus, a potentially greater storage sensitivity under higher relative humidity, favoring the respiratory activity of the seeds (Ellis et al., 1987).

As in germination, we did not detect, in the cold test, differences between the unaged lots of the three hybrids (lots 1 , 4 and 7) stored in a cold and dry chamber, holding, in a way, the same performance verified before storage (Table 2). In general, if the cold test results approach those obtained from the standard germination test, there is a great possibility that these lots present the ability to germinate under a wide range of moisture conditions and soil temperature (Cícero and Vieira, 1994).

Still in the cold and dry chamber $\left(\mathrm{A}_{1}\right)$, although the cold test has detected declines in the performance of seeds in lots of hybrids A and B (lots 3 and 5) at the end of storage, we verified values of $89 \%$ and $84 \%$, which indicate superiority of these lots when compared to lot 9 (hybrid C), aged for the same period, but with a value of $65 \%$ at the end of storage, indicating again that the storage potential of this hybrid was lower than the others (Table 2).

In the laboratory environment $\left(A_{2}\right)$, the seeds of hybrids $\mathrm{A}$ and $\mathrm{B}$, which were not subjected to aging (lots 1 and 4 ) also showed, after the cold test, a mean percentage of normal seedlings superior to those observed for the seeds of hybrid C (lot 7) at six months of storage.

In lots aged for 96 hours, that is, lots with reduced physiological potential (lots 3, 5 and 9) a reduction in the performance of the seeds was observed, which presented a different behavior in the laboratory $\left(\mathrm{A}_{2}\right)$ and controlled $\left(20{ }^{\circ} \mathrm{C}\right.$ and $70 \%$ UR $\left.-\mathrm{A}_{3}\right)$ environments from the third month of storage, with a decrease of over 40 percentage points for the seeds of lot 3 (hybrid A) and lot 9 (hybrid C), while for the seeds of lot 5 (hybrid B) the decrease was 26 percentage points (Table 2), which proved, also, the superiority of the seeds of hybrid B. 

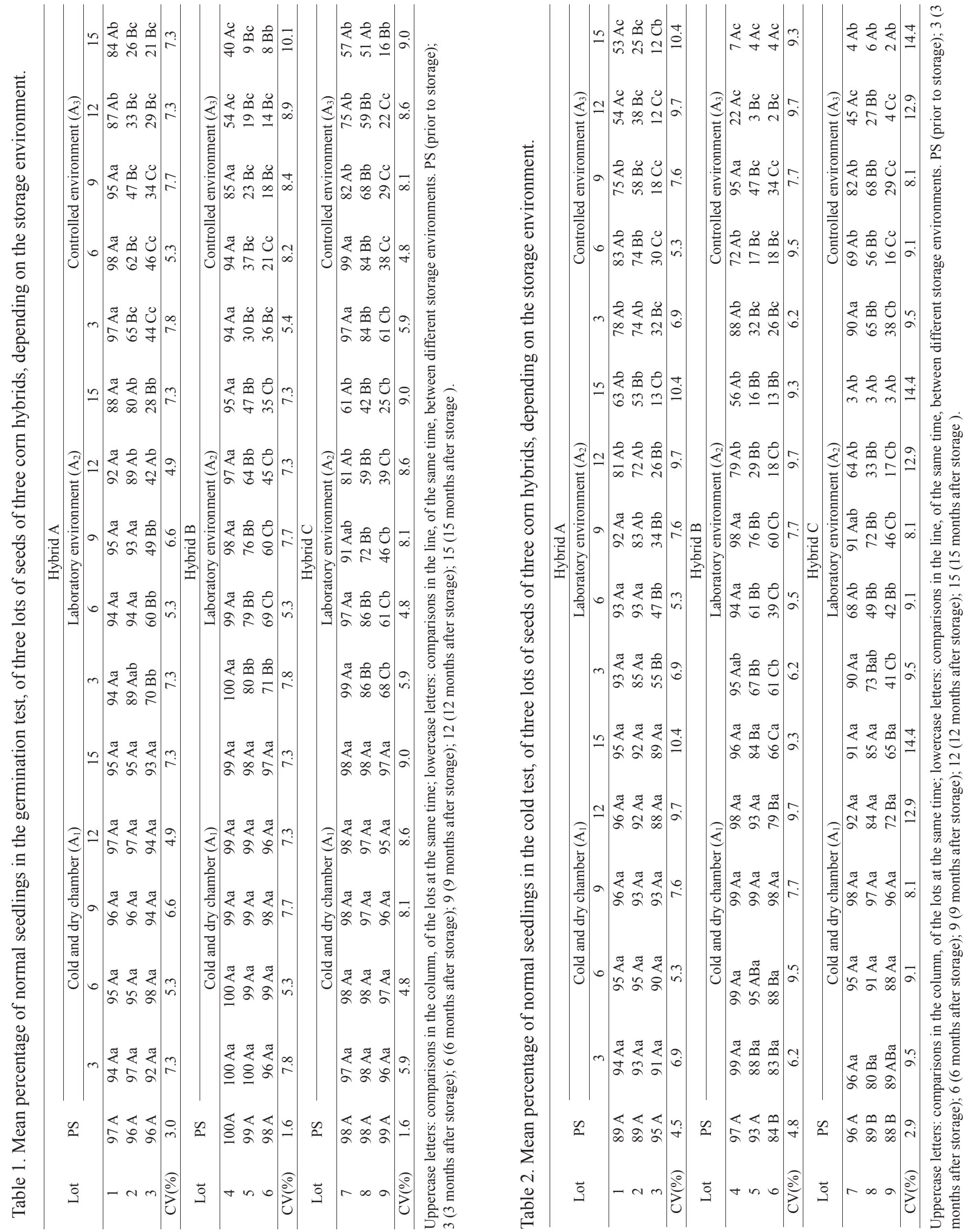


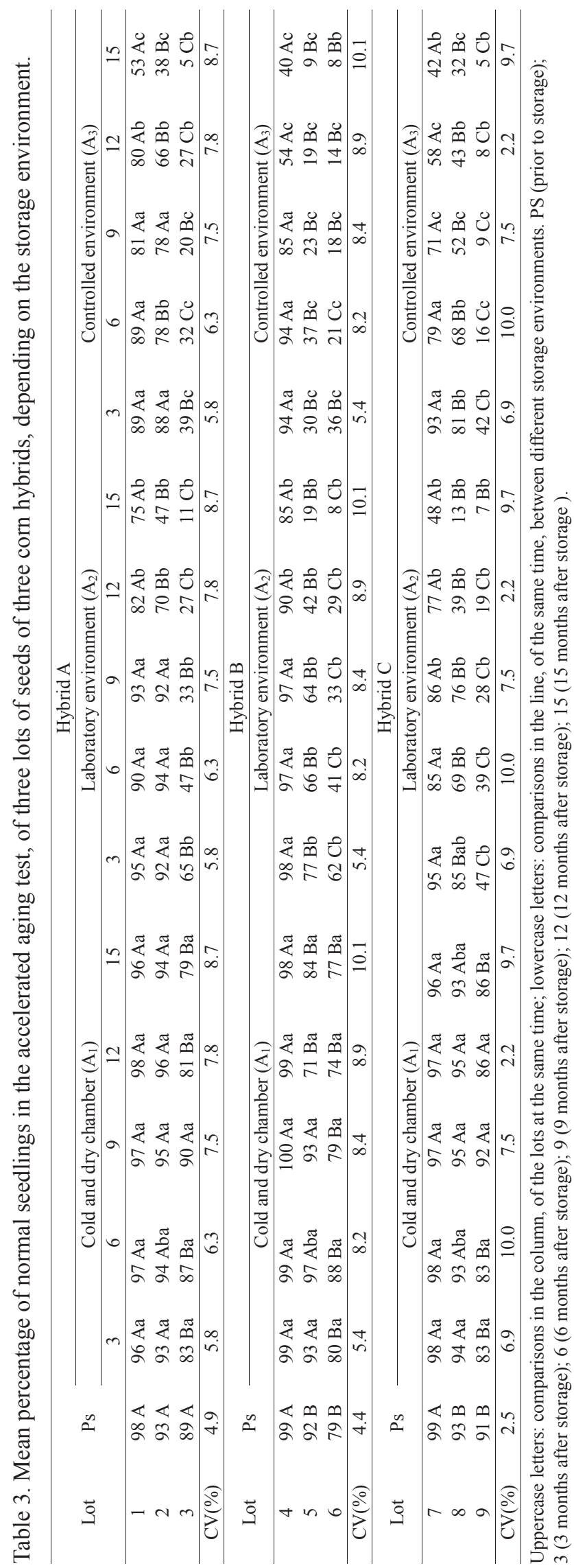

On Table 3 are the germination means after accelerated aging. For all hybrids, there were reductions in vigor throughout storage, with the exception of lots of higher (lots 1, 4 and 7) and intermediate physiological potential of hybrids $A$ and $B$ (lots 2 and 5), stored in a cold and dry chamber.

For hybrids A and B (lots 1 and 4), there was a reduction in the later stages of storage (12 and 15 months), in seeds stored under environments $\mathrm{A}_{2}$ (laboratory) and $\mathrm{A}_{3}\left(20{ }^{\circ} \mathrm{C}\right.$ and $70 \%$ $\mathrm{RH})$. It is noteworthy that the seeds of hybrid $B$ (lot 4), with 15 months of storage in the environment $\mathrm{A}_{2}$ and nine months in the environment $\mathrm{A}_{3}$ showed germination percentage of $85 \%$ after accelerated aging. This shows, again, the superiority of hybrid B, because the seeds of the other hybrids had their vigor reduced faster; the seeds of hybrid A (lot 1) showed a reduced vigor at 12 months, and those of hybrid $\mathrm{C}$ (lot 7) at six months of storage (Table 3). Under the conditions of this test, seeds with lower physiological potential deteriorated more rapidly, affecting the germination after the accelerated aging period (Dutra and Vieira, 2004).

Similarly to the cold test, drastic reductions were observed in the germination percentage after accelerated aging at the end of the storage period in environments $A_{2}$ and $A_{3}$, mainly for the lots with intermediate and low physiological potential (lots 2, 3, 5, 6, 8 and 9) (Table 3). The fact that the seeds in these lots are already in an advanced degree of deterioration may further undermine the maintenance of the physiological potential of the seeds during storage, because the high moisture content and high temperature favor the respiratory activity of the seeds (Ellis et al., 1987), conditions found in the accelerated aging test.

On the other hand, in relation to the electrophoretic analysis, an increased activity of catalase (CAT) was verified in seeds of lots 3, 5 and 9, stored in a cold and dry chamber $\left(\mathrm{A}_{1}\right)$, which were submitted to artificial aging for 96 hours. CAT is an enzyme present in the peroxisomes of cells and has the function of catalyzing the decomposition of hydrogen peroxide into molecular oxygen and water without the production of free radicals and is, thus, very important in cellular detoxification (Hallinwell and Gutteridge, 1990).

The deterioration during storage, especially in laboratory conditions $\left(\mathrm{A}_{2}\right)$ and in a controlled environment $\left(\mathrm{A}_{3}\right)$, may have induced the acceleration of oxidative processes and production of free radicals. This can be evidenced by the increased activity of the catalase (CAT) enzyme at the beginning of storage (month 0 ) in these environments (Figure $1 \mathrm{~B}$ and $1 \mathrm{C}$ ), where the enzyme activity was reduced in seeds stored in subsequent periods, and may be associated with the deterioration level, with lower expression of this peroxideremoving enzyme. 


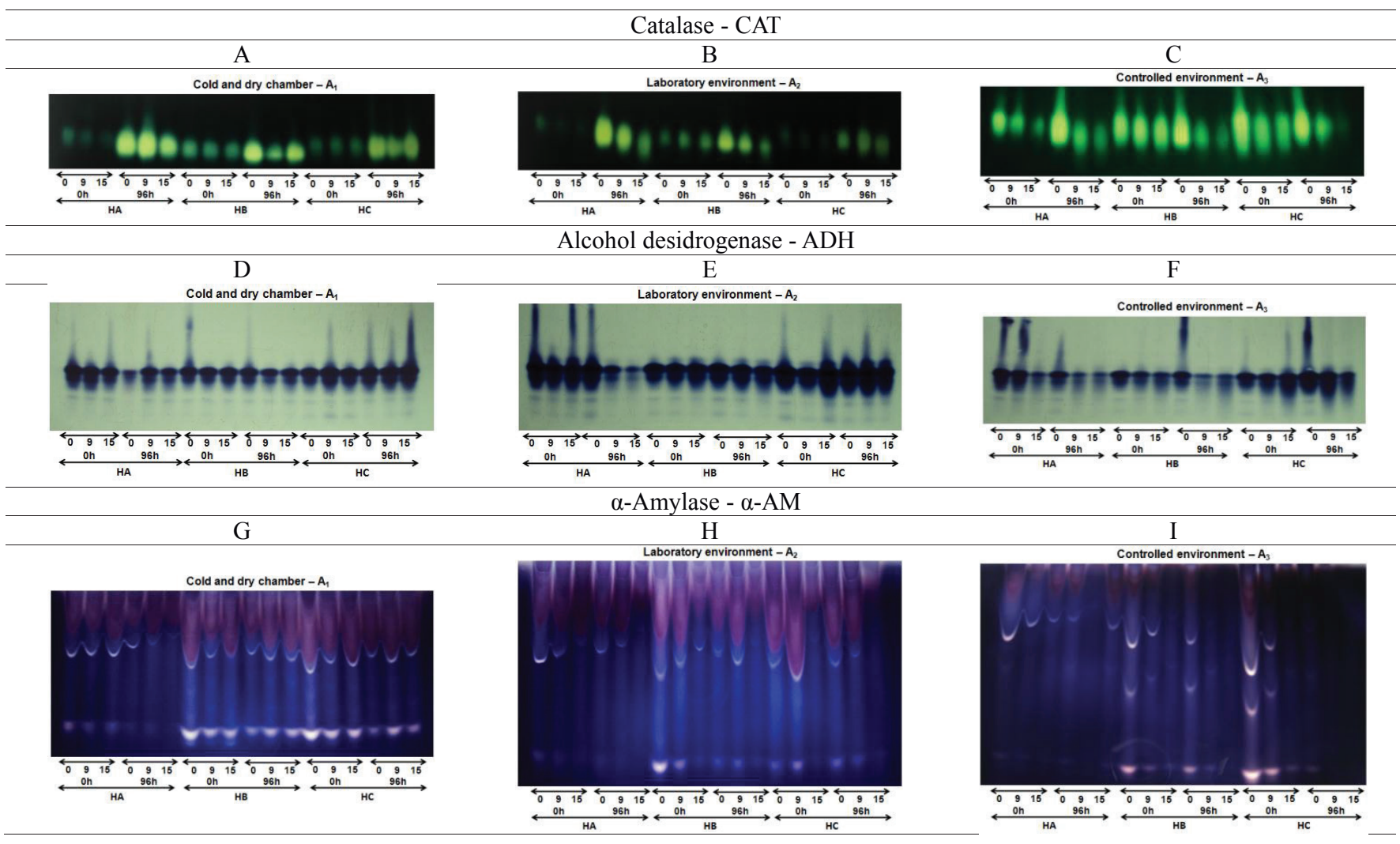

Figure 1. Enzyme pattern of catalase (CAT), alcohol dehydrogenase (ADH) and $\alpha$-amylase ( $\alpha$-AM) enzymes in seeds of hybrid A (lots 1 and 3), B (lots 4 and 5) and C (lots 7 and 9), subjected to 0, 9 and 15 months of storage, in three conditions (cold and dry chamber - A1, laboratory environment - A2 and controlled environment - A3).

In the controlled environment $\left(\mathrm{A}_{3}\right)$, there was a higher CAT activity than in the other two environments. This may have happened due to the conditions in this environment, $20{ }^{\circ} \mathrm{C}$ and $70 \% \mathrm{RH}$, which may have contributed to accelerate the deterioration of seeds.

In the most deteriorated seeds there was a marked decrease or even absence of activity of this enzyme, as observed in the seeds of hybrid $\mathrm{C}$ stored for 15 months in a controlled environment (Figure 1C). Because catalase is one of the "scavenger" enzymes, that is, it removes free radicals, the loss of activity of this enzyme may partially explain the fact that aged seeds accumulate more peroxides.

The results observed in this study reinforce those of Corte et al. (2010) and Nakada et al. (2010), which noted an increase in lipid peroxidation with increasing deterioration of the seeds. Thus, the reduced activity of catalase (CAT) can make the seeds more sensitive to the effects of free radicals and enhance peroxide formation in cells, making the seeds more subject to loss of viability. This can be confirmed by the reduction in germination in the final periods of storage (Table 1), especially in seeds of hybrid $\mathrm{C}$, in a laboratory environment $\left(\mathrm{A}_{2}\right)$ and in a controlled environment $\left(\mathrm{A}_{3}\right)$.
Commonly used in studies on the deterioration of seeds, dehydrogenase alcohol (ADH) has a known action on the anaerobic metabolism of plants, encouraging the reduction of acetaldehyde to ethanol (Taiz and Zeiger, 2004). A higher activity of the ADH enzyme was observed in seeds of hybrid $\mathrm{C}$ in the laboratory environment $\left(\mathrm{A}_{2}\right)$ and in the controlled environment $\left(\mathrm{A}_{3}\right)$ (Figures $1 \mathrm{E}$ and $1 \mathrm{~F}$ ). Increased activity of this enzyme in seeds of this hybrid kept under unfavorable conditions of temperature and relative humidity, such as what occurred in these environments, may have promoted the increased breathing that occurs in seeds that are in a more advanced process of deterioration. With the subsequent production of ethanol, toxic to the seeds, it is possible to relate these results to those observed in germination and vigor tests, since out of the three hybrids studied, hybrid $\mathrm{C}$ was shown to be the most sensitive in this environment.

A reduction in the activity of $\alpha$-amylase ( $\alpha$-AM) during storage was observed, for all hybrids studied, in all environments (Figure 1G, 1H and 1I). In several studies, relationships have been observed between loss of viability and decreased activity of this enzyme. In wheat seeds artificially aged, Ganguli and Sen-Mandi (1993) showed that the enzyme 
$\alpha$-AM was synthesized in reduced rates by aleurone layer. According to the authors, deteriorative changes may occur in the aleurone layer during aging. These changes may determine the decrease in amylase production which in turn affects the germination. This was verified through vigor tests (Tables 2 and 3), where the seed performance was reduced during storage.

The $\alpha$-amylase $(\alpha-\mathrm{AM})$ is an important enzyme in the hydrolysis of starch, accounting for $90 \%$ of the amylase activity in corn seeds. Usually not present in dry seeds, being synthesized and secreted by the aleurone layer (Kigel and Galili, 1995). During seed development, the aleurone layer serves as stock reserves, while in germination, it constitutes a source of enzymes for the mobilization of reserves (Fincher, 1989).

The observations made in the germination and vigor tests and in isoenzyme analyzes confirmed, in general, that for all hybrids assessed, the cold and dry chamber $\left(\mathrm{A}_{1}\right)$ was the environment that provided better conditions for seed storage, followed by the laboratory environment $\left(\mathrm{A}_{2}\right)$. The explanation for reduction of physiological potential found in seeds stored in the laboratory environment $\left(\mathrm{A}_{2}\right)$ can be associated to the fact that, during the entire period of the experiment, fluctuations of temperature and relative humidity in this environment certainly may have contributed for the reduced storage potential of the seeds. The storage in controlled environment $\left(\mathrm{A}_{3}\right)$ caused a greater reduction of the physiological potential for the high relative humidity present in this environment.

Regarding the hybrids, it was possible to detect differences in the storage potential, especially in the laboratory $\left(\mathrm{A}_{2}\right)$ and controlled $\left(\mathrm{A}_{3}\right)$ environments, where, in general, the seeds of hybrid $\mathrm{B}$ maintained their physiological potential for a longer period, followed by hybrids A and C. The seeds of hybrid B preserved their physiological potential for around 15 months in the laboratory environment $\left(\mathrm{A}_{2}\right)$ and nine months in the controlled environment $\left(\mathrm{A}_{3}\right)$; the seeds of hybrid $\mathrm{A}$ for 12 months in $\mathrm{A}_{2}$ and 6 months in $\mathrm{A}_{3}$; and the seeds of hybrid $\mathrm{C}$ for 6 months in $A_{2}$ and $A_{3}$, based on germination test, cold test and accelerated aging. This result was interesting because the condition created in environment $\mathrm{A}_{3}\left(20^{\circ} \mathrm{C}\right.$ and $\left.70 \% \mathrm{RH}\right)$ for this research allowed to anticipate obtaining information about the physiological potential; this makes it possible to plan the strategy to be adopted by companies producing corn seeds for storage and marketing of seeds.

Investment by companies for the development of new corn cultivars is high, justifying the monitoring of the physiological potential of seeds in this process, which ensures the conservation of the physiological potential during storage. This aspect is important, since the storage conditions are varied until the moment of sowing. Thus, the use of tools available in the field of seed production and technology, for example, molecular markers of protein and tests to evaluate the physiological potential of seeds, are important in breeding programs.

\section{Conclusions}

There is variation in the vigor and activity of enzymes in the storage potential of corn seeds under the influence of their genotype.

The storage potential of seeds of different genotypes of corn is evaluated safely associating germination and vigor test results with assessments of isoenzyme activities.

Storage under sub-optimal conditions of temperature and relative humidity is adequate to promote differences in the intensity and speed of deterioration of seeds of corn genotypes.

\section{References}

ALFENAS, A.C. (Ed.). Eletroforese e marcadores bioquímicos em plantas e microorganismos. 2.ed. Viçosa, MG: UFV, 2006. 627p.

ALSCHER, R.G.; ERTURK, N.; HEALTH, L.S. Role of superoxide dismutases (SODs) in controlling oxidative stress in plants. Journal of Experimental Botany, v.53, n.372, p.1331-1341, 2002. http://www.scielo.br/scielo.php?script=sci nlinks\&ref $=000059 \& \mathrm{pid}=\mathrm{s} 0101-3122201000010001000001 \& \operatorname{lng}=\mathrm{en}$

ANDRADE, R.V.; BORBA, C.S. Fatores que afetam a qualidade das sementes. In: EMBRAPA, Centro Nacional de Milho e Sorgo. Tecnologia para produção de sementes de milho. EMBRAPA, p.7-10, 1993.

BRASIL. Ministério da Agricultura, Pecuária e Abastecimento. Regras para análise de sementes. Ministério da Agricultura, Pecuária e Abastecimento. Secretaria de Defesa Agropecuária. Brasília: MAPA/ACS, 2009. 395p. http:// www.bs.cca.ufsc.br/publicacoes/regras\%20analise $\% 20$ sementes.pdf

CARVALHO, N.M.; NAKAGAWA, J. Sementes: ciência, tecnologia e produção. 4 ed. Jaboticabal: FUNEP, 2000. 588p.

CASEIRO, R.F.; MARCOS-FILHO, J. Procedimentos para a condução do teste de frio visando a avaliação do vigor de sementes de milho. Scientia Agricola, v.57, p.459-466, 2000. http://www.scielo.br/scielo.php?pid=s0101$31222002000200002 \&$ script $=$ sci_arttext

CICERO, S.M.; VIEIRA, R.D. Teste de frio. In: VIEIRA, R.D.; CARVALHO, N.M. (Ed.) Testes de vigor em sementes. Jaboticabal: FUNEP, p.151-164, 1994.

COPELAND, L.O.; McDONALD, M.B. Seed science and techonology. $4^{\text {th }}$ ed. New York: Chapman \& Hall, 409p. 2001.

CORTE, V.G.; BORGES, E.E.L.; LEITE, H.G.; PEREIRA, B.L.C.; GONÇALVES, J.F.C. Estudo enzimático da deterioração de sementes de Melanoxylon brauna submetidas ao envelhecimento natural e acelerado. Revista Brasileira de Sementes, v.32, n.1, p.83-91, 2010. http://www.scielo. br/scielo.php?pid=s0101-31222010000100010\&script=sci_abstract\&tlng=pt

DUTRA, A.S.; VIEIRA, R.D. Envelhecimento acelerado como teste de vigor para sementes de milho e soja. Ciência Rural, v.34, n.3, p.715-721, 2004 http://www.scielo.br/scielo.php?script=sci_nlinks\&ref=000064\&pid=s0101$3122200700010002700004 \& \operatorname{lng}=$ en 
ELLIS, R.H.; SIMON, G.; COVELL, S. The influence of temperature on seed germination rate in grain legumes. Journal of Experimental Botany, v.38, p.1033-1043, 1987. http://www.scielo.br/scielo.php?script=sci_ nlinks\&ref $=000090 \&$ pid $=$ s0100-204x200200050001500011\&lng=en

FERREIRA, D.F. SISVAR: um programa para análises e ensino de estatística. Revista Symposium, v.6, p.36-41, 2008. http://www. scielo.br/scielo.php? script $=$ sci_nlinks\&ref $=000085 \& \mathrm{pid}=\mathrm{S} 1413$ $7054201100030001300007 \& \operatorname{lng}=$ en

FINCHER, G.B. Molecular and cellular biology associated with endosperm mobilization in germinating cereal grains. Annual Review Plant Physiology Molecular Biology, v.40, p.305-346, 1989. http:// www.scielo.br/scielo.php?script=sci_nlinks\&ref=000069\&pid=S0101$3122200200020001900006 \& \operatorname{lng}=$ en

GANGULI, S.; SEN-MANDI, S. Effects of ageing on amylase activity and scutellar cell structure during imbibition in wheat seed. Annals of Botany, v.71， n.5, p.411-416, 1993. http://www.scielo.br/scielo.php?script=sci nlinks\&ref $=000121 \&$ pid $=$ S0101-3122200700020002600007\&lng=en

HALLINWELL, B.; GUTTERIDGE, J.M.C. Role of free radicals and catalytic metal ions in human disease. Methods of Enzimology, v.186, n.1, p.1-85, 1990. http://www.scielo.br/scielo.php?script=sci nlinks\&ref $=000059 \&$ pid $=$ S0103-8478200700050001900011\&lng=en

HARRINGTON, J.F. Seed storage and longevity. In: KOZLOWSKI, T.T. Seed biology. New York: Academic Press, v.3, p.145-245, 1972. http:// www.scielo.br/scielo.php?script $=$ sci_nlinks\&ref=000036\&pid=S0006$8705198500010003100005 \& \operatorname{lng}=$ en

JIANHUA, Z.; McDONALD, M.B. The saturated salt accelerated aging test for small-seeded crops. Seed Science and Technology, v.25, n.1, p.123-131, 1997. http://www.scielo.br/scielo.php?script=sci_nlinks\&ref=000067\&pid=s0101$3122201200010000700007 \& \operatorname{lng}=$ en
KIGEL, J.; GALILI, G. Seed development and germination. New York: Marcel Dekker, 1995. 853p.

MARCOS-FILHO, J. Teste de envelhecimento acelerado. In KRZYZANOWSKI, F.C., VIEIRA, R.D., FRANÇA-NETO, J.B. (Ed.). Vigor de sementes: conceitos e testes. Londrina: ABRATES, 1999. p.3.1-3.24.

MARCOS-FILHO, J.; CICERO, S.M.; SILVA, W.R. Avaliação da qualidade fisiológica das sementes. Piracicaba: FEALQ, 1987. 230p.

NAKADA, P.G.; OLIVEIRA, J.A.; MELO, L.C.; SILVA, A.A.; SILVA, P.A.; PERINA, F.J. Desempenho durante o armazenamento de sementes de pepino submetidas a diferentes métodos de secagem. Revista Brasileira de Sementes, v.32, n.3, p.42-51, 2010. http://www.scielo.br/pdf/rbs/v32n3/v32n3a05.pdf

SANTOS, C.M.R.; MENEZES, N.L.; VILLELA, F.A. Alterações fisiológicas e bioquímicas em sementes de feijão envelhecidas artificialmente Revista Brasileira de Sementes, v.26, n.1, p.110-119, 2004. http:// www.scielo.br/scielo.php? script $=$ sci_nlinks\&ref $=000142 \&$ pid $=$ S0101$3122200800030001700022 \& \operatorname{lng}=\mathrm{en}$

STEIN, W.L.; SLABAUCH, P.E.; PLUMER, A.P. Harvesting, processing, and storage of fruits seeds. In: Seeds of woody plants in the United States, Agricultural Handbook, n.450, Forest Service, USDA, Washington D.C., 1974. p. $98-125$

TAIZ, L.; ZEIGER, E. Plant physiology. Califórnia: Cummings, 2004. 565p. 